\title{
Macro Invertebrates as Indicators of Anthropogenic Pollution of the River Mirusha in Kosovo
}

\author{
Arbnora Bytyqi ${ }^{1}$, Ferdije Zhushi Etemi ${ }^{1}$, Pajtim Bytyqi ${ }^{2 *}$, Murtezan Ismaili ${ }^{2}$ \\ ${ }^{1}$ Department of Biology, Faculty of Mathematics and Natural Sciences, University of Prishtina, Mother \\ Teresa 5, Prishtina 10000, Kosovo \\ ${ }^{2}$ South East European University, Faculty of Contemporary Sciences and Technologies, Ilindenska 335, \\ Tetovo Macedonia
}

Corresponding author: PajtimBytyqi, email:pajtim.bytyqi@ hotmail.com, phone:+37744766442

\begin{abstract}
The sensitivity of macro invertebrates to changes in environmental quality made them an integral part of any bio-monitoring program. In our research macro invertebrates were used to evaluate the anthropogenic pollution in the river Mirusha. The samples were collected during January to April 2015 in three locations along the river.Based on the values of physic-chemical parameters, total taxa number, Hilsenhoff Biotic index (HBI) and Shannon Winner diversity index $(H)$, the water of the river is fair to fairly poor quality as a result of disturbances caused by anthropogenic activities.
\end{abstract}

Keyëords: Macro invertebrates, anthropogenic pollution, Mirusha, disturbance

\section{Introduction}

Today, water pollution has become a very serious problem, and it includes the chemical, physical and biological components of waters. As the main sources of water pollution in Kosovo in the recent years are waste waters, agriculture and industrial activities which discharges directly into the water collection channels and go into the rivers. Animals, starting from the simplest (invertebrates) and to those with more complex body structure, can be used in bio-monitoring programs. Benthic macro-invertebrates, are doubtless the most frequently used organisms for bioindication in standard water management (De Pauwet al., 1992; Rosenberg and Resh, 1993; Metcalfe- Smith, 1994; Heringet al., 2004).Evaluating the abundance and diversity of benthic macroinvertebrates in a waterbody gives us an indication of the biological condition of that waterbody.

Macro-invertebrates react against the physical and chemical changes of the environment, therefore, their composition should represent different events which took place in the water during every phase of their development (Cairns and Pratt, 1993). Water pollution affects the biodiversity of water environment, thus the species composition changes from natural to tolerant species against different pollutants. The use of macro-invertebrates in biological evaluation of water bodies have some advantages such as: they can be found in most aquatic habitats, they are sensitive to changes of physical and chemical conditions of the water, they are the food source for many species of fish, they have limited mobility, so they cannot escape pollution events, they are small, they are easy to collect and identify.

Considering the requirements of the EU WFD, the composition and abundance of macroinvertebrate fauna, apart from aquatic flora or fish fauna, constitutes one of the quality elements for the classification of the ecological status of streams (WFD, 2000).

River Mirusha is the left tributary of the Drini I Bardhë basin. It is one of the most beautiful rivers in Kosovo.Due to hydrological, geomorphologic and landscape importance, in 1983 this river has been put under protection by the National authorities as a third category monument according to IUCN.

Mirusha derives in the mountains of Carraleva, it has a length of $37 \mathrm{~km}$, and flows in an altitude from 795-360 meters. The average flow is $1.2 \mathrm{~m}^{3} / \mathrm{s}$, while the average water level is $0.65 \mathrm{~cm}$. The river covers an area of $336.7 \mathrm{~km}^{2}$, around $3.1 \%$ of the total land area of Kosovo 
In its middle and down stream, river Mirush acreates a canyon around $2 \mathrm{~km}$ long, where 16 lakes of different shapes and sizes have been created, connected to each other with 12 spectacular waterfalls. Due to the canyon beauty, the waterfalls of Mirusha attract many tourists, affecting positively in the development of tourisms in this area, unfortunately this resulted with increased anthropogenic impact and disturbance in the river.

\section{Materials and Methods}

\subsection{Study area}

Samples of macro invertebrates were collected in three localities (table 1.) along the river with different antropogenic impact.

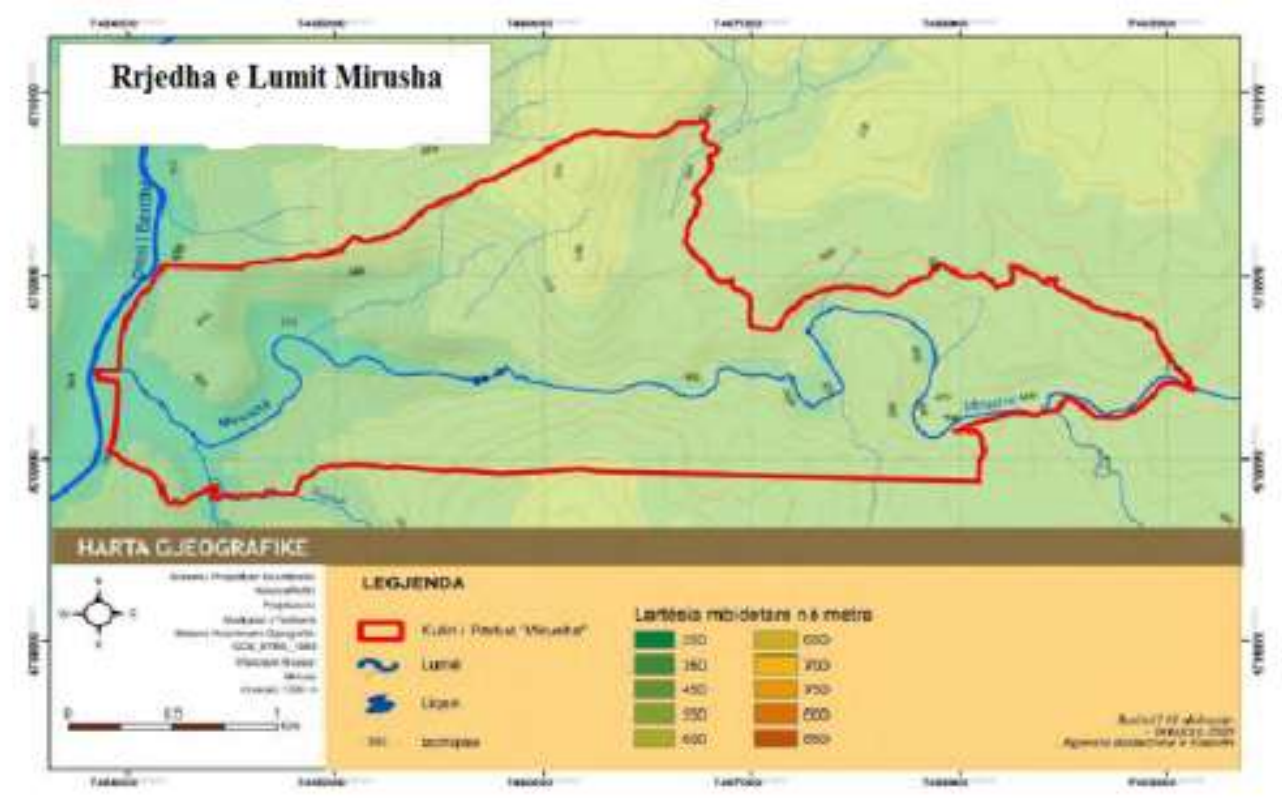

Fig. 1. River Mirusha Flow

The first sampling locality of macro invertebrates is in the upstream in the river spring, where a branch of thermal water deriving from the therme of Banja e Malisheves joins the river. The substrate of the river consists of stone, grit and silt.

The second sampling locality was in the center of the town of Malisheva. It this locality the untreated waste waters from the municipality as well as used waters from the hospitality and other economic operators discharge directly into the river.

It should be mentioned that the river bed in this area is cemented as an action of municipal authorities to maintain it.

TABLE I. Macro invertebrate sampling localities

\begin{tabular}{|c|c|c|c|}
\hline Locality & $\mathrm{X}$ & Y & Altitude \\
\hline $\begin{array}{l}\text { L1- Banja e Malisheves(upstream of the } \\
\text { river) }\end{array}$ & $42^{\circ} 28^{\prime} 4.52^{\prime \prime} \mathrm{N}$ & $20^{\circ} 46^{\prime} 3.42^{\prime \prime E}$ & $538 \mathrm{~m}$ \\
\hline L2-Malisheva (middle stream) & $42^{\circ} 29^{\prime} 7.87^{\prime \prime} \mathrm{N}$ & $20^{\circ} 43^{\prime} 59.13^{\prime \prime E}$ & $521 \mathrm{~m}$ \\
\hline L3-Mirusha waterfalls-downstream & $42^{\circ} 31^{\prime} 24.80^{\prime \prime} \mathrm{N}$ & $20^{\circ} 34^{\prime} 55.84^{\prime \prime} \mathrm{E}$ & $428 m$ \\
\hline
\end{tabular}


The third sampling locality was at the first waterfall in the park of Mirusha. The width of this locality is about $5.50-10 \mathrm{~m}$, while the altitude is $428 \mathrm{~m}$. The substrate of the river is composed from stones, gravel and silt but also from the garbage deposited by the visitors of this monument and from two improvised restaurants operating in this area. The depth of the river is different from place to place and it goes up to $90.5 \mathrm{~cm}$. In both sides of the river, the vegetation is quite developed, composed of grass, bushes and woods dominated by willow.

Macroinvertebrates were collected with a net, depending on the river depth and substrate structure, the Surber's net and D frame net with $500 \mu \mathrm{m}$ mesh size have been used. In each sampling locality multihabitat sampling technique was used (Hering, 2004). Samples were preserved in $75 \%$ alcohol and transported to the laboratory of Zoology at the Department of Biology of the University of Prishtina. In the laboratory the macroinvertebrate samples were sorted and identified to the taxonomic level with the help of binocular stereomicroscope and adequate keys. (Tachet at al.,2010; Merritt and Cummins,1984)

Parallel to biological sampling, the measurement of physical and chemical parameters of water was done. In order to assess the pollution from the anthropogenic impact, we have calculated the total number of taxa as well as two indexes: Hilsenhoff Biotic Index -BI (Bode et al. 1988; Hilsenhoff, 1997), which is used to measure the organic pollution and is based on the tolerance value of taxons against the oxygen level in the water, and the Shannon-Wiener diversity index $-\mathrm{H}$, which represents the diversity of the species in a sample.

\section{Results}

Values of the physical and chemical parameters have been shown below on the Table 2.

TABLE II. The values of physical and chemical parameters in surveyed localities

\begin{tabular}{|c|c|c|c|c|c|c|c|c|c|c|c|c|c|c|}
\hline \multicolumn{6}{|c|}{ January 2015} & \multicolumn{3}{|c|}{ February 2015} & \multicolumn{3}{|c|}{ March 2015} & \multicolumn{3}{|c|}{ April 2015} \\
\hline Parametri & & $\begin{array}{c}\text { me } \\
\text { asu } \\
\text { re }\end{array}$ & L1 & $\mathrm{L} 2$ & L2 & L1 & L2 & L3 & L1 & $\mathrm{L} 2$ & L3 & L1 & $\mathrm{L} 2$ & L3 \\
\hline $\begin{array}{l}\text { Water } \\
\text { temperature }\end{array}$ & $\mathrm{Wt}$ & ${ }^{0} \mathrm{C}$ & 18 & 8.5 & 6.5 & 19.2 & 10.3 & 8.5 & 20 & 11 & 8 & 24.5 & 15.5 & 13.2 \\
\hline $\begin{array}{l}\text { Total } \\
\text { suspended } \\
\text { matter }\end{array}$ & TSM & $\begin{array}{c}\mathrm{mg} \\
/ 1\end{array}$ & 251 & 239 & 206 & 271 & 298 & 200 & 319 & 312 & 290 & 332 & 318 & 298 \\
\hline $\mathrm{pH}$ & $\overline{\mathrm{pH}}$ & $\begin{array}{l}0- \\
14 \\
\end{array}$ & 7.21 & 7.99 & 7.61 & 7.29 & 8.32 & 7.46 & 7.22 & 8.52 & 8.04 & 7.15 & 8.63 & 8.11 \\
\hline \multicolumn{15}{|c|}{ ParametratKimik } \\
\hline $\begin{array}{l}\text { Dissolved } \\
\text { oxygen }\end{array}$ & DO & $\begin{array}{c}\mathrm{mg} / \\
1\end{array}$ & 8.50 & 7.10 & 9.80 & 8.90 & 6.60 & 10.50 & 9.00 & 6.50 & 8.70 & 8.90 & 6.30 & 9.48 \\
\hline $\begin{array}{l}\text { Oxygen } \\
\text { Saturity }\end{array}$ & OS & $\%$ & 89.76 & $\begin{array}{c}60.6 \\
8\end{array}$ & 79.74 & 96.32 & 58.88 & 89.74 & $\begin{array}{c}99.0 \\
1\end{array}$ & 58.93 & $\begin{array}{c}88.6 \\
0\end{array}$ & $\begin{array}{c}99.7 \\
0\end{array}$ & $\begin{array}{c}65.8 \\
0\end{array}$ & $\begin{array}{c}94.4 \\
2\end{array}$ \\
\hline $\begin{array}{l}\text { Total } \\
\text { suspended } \\
\text { matter }\end{array}$ & TSM & $\begin{array}{c}\mathrm{mg} / \\
1\end{array}$ & 0.30 & $\begin{array}{c}22.5 \\
0\end{array}$ & 8.90 & 0.80 & 19.80 & 11.9 & $\begin{array}{c}<0 . \\
1\end{array}$ & 55.20 & $\begin{array}{c}35.5 \\
0\end{array}$ & $\begin{array}{c}<0 . \\
1\end{array}$ & $\begin{array}{c}26.7 \\
0\end{array}$ & $\begin{array}{c}15.3 \\
0\end{array}$ \\
\hline $\begin{array}{l}\text { Chemical } \\
\text { Oxygen } \\
\text { Demand }\end{array}$ & $\begin{array}{c}\mathrm{CO} \\
\mathrm{D}\end{array}$ & $\begin{array}{c}\mathrm{mg} / \\
1\end{array}$ & 1.80 & $\begin{array}{c}28.6 \\
0\end{array}$ & 10.50 & 3.10 & 80.00 & 44.50 & 7.30 & 77.60 & $\begin{array}{c}49.5 \\
0\end{array}$ & 8.70 & $\begin{array}{c}40.4 \\
0\end{array}$ & $\begin{array}{c}12.0 \\
0\end{array}$ \\
\hline $\begin{array}{l}\text { Biochemica } \\
\text { l Oxygen } \\
\text { Demand }\end{array}$ & $\begin{array}{c}\mathrm{BO} \\
\mathrm{D}\end{array}$ & $\begin{array}{c}\mathrm{mg} / \\
1\end{array}$ & 0.95 & $\begin{array}{c}15.1 \\
2\end{array}$ & 5.55 & 1.89 & 37.00 & 23.53 & 4.10 & 1.89 & $\begin{array}{c}12.3 \\
0\end{array}$ & 4.60 & $\begin{array}{c}17.8 \\
0\end{array}$ & 5.70 \\
\hline Detergents & DET & $\begin{array}{c}\mathrm{mg} / \\
\mathrm{l}\end{array}$ & $<0.1$ & 0.10 & $<0.1$ & $<0.1$ & 0.20 & 0.10 & $\begin{array}{c}<0 . \\
1\end{array}$ & 0.40 & 0.15 & $\begin{array}{c}<0 . \\
1\end{array}$ & 0.30 & 0.10 \\
\hline Nitrites & $\mathrm{NI}_{3}^{-}$ & $\begin{array}{c}\mathrm{mg} / \\
1\end{array}$ & 5.80 & 6.20 & 5.20 & 6.20 & 14.10 & 7.30 & 4.80 & 8.60 & 6.30 & 5.40 & 5.40 & 4.50 \\
\hline Chlorides & $\mathrm{Cl}^{-}$ & $\begin{array}{c}\mathrm{mg} / \\
1\end{array}$ & 11.60 & $\begin{array}{c}15.8 \\
0\end{array}$ & 13.80 & 10.90 & 20.60 & 14.40 & $\begin{array}{c}12.8 \\
0\end{array}$ & 19.60 & $\begin{array}{c}16.2 \\
0\end{array}$ & $\begin{array}{c}13.5 \\
0\end{array}$ & $\begin{array}{c}21.4 \\
0\end{array}$ & $\begin{array}{c}16.6 \\
0\end{array}$ \\
\hline
\end{tabular}




\begin{tabular}{|c|c|c|c|c|c|c|c|c|c|c|c|c|c|c|}
\hline Phosphates & $\mathrm{PO}_{4}{ }^{3}$ & $\mathrm{mg} /$ & 0.02 & 0.32 & 0.12 & 0.02 & 0.98 & 0.13 & 0.04 & 0.34 & 0.26 & 0.16 & 0.43 & 0.28 \\
\hline $\begin{array}{l}\text { Total } \\
\text { phosphorus }\end{array}$ & $\mathrm{P}_{\text {tot }}$ & $\begin{array}{c}\mathrm{mg} / \\
\mathrm{l}\end{array}$ & 0.06 & 0.91 & 0.33 & 0.09 & 2.56 & 1.29 & 0.22 & 2.28 & 1.47 & 0.30 & 1.27 & 0.43 \\
\hline Sulphates & $\mathrm{SO}_{4}{ }^{2}$ & $\begin{array}{c}\mathrm{mg} / \\
\mathrm{l}\end{array}$ & 4.45 & 9.12 & 7.23 & 4.87 & 9.99 & 7.35 & 5.15 & 18.60 & $\begin{array}{c}13.0 \\
8\end{array}$ & 5.37 & $\begin{array}{c}11.3 \\
5\end{array}$ & 9.22 \\
\hline ammonia & $\mathrm{NH}_{+}$ & $\begin{array}{c}\mathrm{mg} / \\
\mathrm{l}\end{array}$ & 0.005 & $\begin{array}{c}0.09 \\
8\end{array}$ & 0.056 & 0.005 & 0.397 & 0.128 & $\begin{array}{c}0.00 \\
9\end{array}$ & 0.389 & $\begin{array}{c}0.14 \\
1\end{array}$ & $\begin{array}{c}0.00 \\
6\end{array}$ & $\begin{array}{c}0.21 \\
2\end{array}$ & $\begin{array}{c}0.08 \\
6\end{array}$ \\
\hline
\end{tabular}

TABLE III: The macro invertebrate composition in the river Mirusha

\begin{tabular}{|c|c|c|c|c|c|c|}
\hline \multirow[b]{2}{*}{ Nr. } & \multicolumn{3}{|c|}{ Taxonomic category } & \multicolumn{3}{|c|}{ Localities } \\
\hline & Order & Family & Species & L1 & L2 & L3 \\
\hline 1 & Trichoptera & Hydropsychidae & Hydropsyche instabilis & + & + & + \\
\hline 2 & & Hydropsychidae & Hydropsych eannguistipenis & - & + & - \\
\hline 3 & & Rhyacophilidae & Rhyacophila fasciata & - & & + \\
\hline 4 & Ephemeroptera & Baetidae & Baetis muticus & - & + & + \\
\hline 5 & & Baetidae & Centroptilum luteolum & - & - & + \\
\hline 6 & & Ephemerellidae & Ephemerellaignita & - & + & + \\
\hline 7 & & Heptagenidae & Heptageniasulphurea & + & - & + \\
\hline 8 & Plecoptera & Perlodidae & Isoperla gramatica & - & - & + \\
\hline 9 & Odonata & Calopterygidae & Calpoteryx splendens & - & + & - \\
\hline 10 & & Gomphidae & Orychogomphus forcipatus & - & + & + \\
\hline 11 & & Libellulidae & Libellula depressa & - & + & + \\
\hline 12 & Diptera & Simulidae & Simulium sp. & - & + & + \\
\hline 13 & & Tipulidae & Tipula sp. & - & + & + \\
\hline 14 & & Tipulidae & Dicranota sp. & - & - & + \\
\hline 15 & & Tabanidae & Tabanus sp. & - & - & + \\
\hline 16 & Oligochaeta & & & - & - & + \\
\hline 17 & Amhipoda & Gamaridae & Gammarus roeseli & + & - & - \\
\hline 18 & Amhipoda & Gamaridae & Gammarus fossarum & - & + & + \\
\hline 19 & Isopoda & Asellidae & Asellus aquaticus & + & - & - \\
\hline 20 & Gastropoda & Physidae & Physa acuta & + & - & - \\
\hline 21 & Gastropoda & Lymnaeidae & Lymnea peregna & + & - & \\
\hline 22 & Hirudinea & Erpobdellidae & Erpobdella octoculata & - & + & + \\
\hline \multirow[t]{2}{*}{23} & Hirudinea & Hirudinidae & Haemopis sanguisuga & - & + & + \\
\hline & Species number & & & 6 & 12 & 17 \\
\hline
\end{tabular}

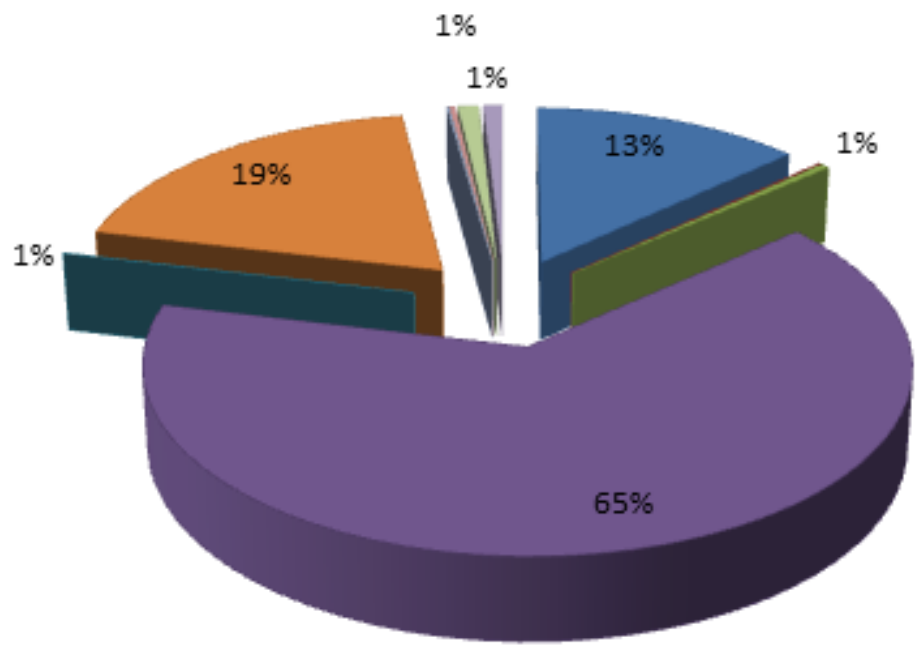

Ephemeroptera

Ple coptera

-Odonata

Diptera

口Oligochaeta

$\square$ Amphipoda

- Isopoda

- Gastropoda

$\square$ Hirudinea

Trichoptera

Fig 2. Pariticipation of animal groups in macroinvertebrate samples 
TABLE IV.Hilsenhoff biotic index (HBI) in three surveyed localities

\begin{tabular}{|lll|}
\hline Localities & HBI & Water quality \\
\hline L1 & 5.58 & Fair \\
\hline L2 & 5.80 & Fairly poor \\
\hline L3 & 5.89 & Fairly poor \\
\hline
\end{tabular}

TABLE V. Shannon- Wiener Diversity Index $(\mathrm{H})$ in the surveyed localities

\begin{tabular}{|c|c|c|c|}
\hline & L1-Banja e Malisheves & L2-Malishevo & $\begin{array}{l}\text { L3-Mirusha } \\
\text { waterfalls }\end{array}$ \\
\hline $\mathrm{Nr}$ of taxa & 6 & 12 & 17 \\
\hline $\begin{array}{l}\mathrm{Nr} \\
\text { specimen/individuals of }\end{array}$ & 557 & 1267 & 1393 \\
\hline $\begin{array}{l}\text { Shannon Wiener- } \\
\text { diversity index }-\mathrm{H}\end{array}$ & 0.06 & 1.11 & 0.88 \\
\hline
\end{tabular}

During our research 3217 macro invertebrate organisms were collected, belonging to 18 families and to 10 taxonomic groups. Insect orders Ephemeroptera, Odonata and Diptera are the richest and have been represented by three families each, while the other groups such as Gastropods, Hirudinea and Trichoptera by two families each. Groups such as Plecoptera, Oligochaetes, Amphipoda and Isopoda were represented by only one family. Regarding the number of taxons in localities, from table 2, it can be seen that the first locality, Banja e Malisheves, is poorer with spices, only six, while on the second locality the number of spices increases in 12, to continue with the third one with 17 species. In the first locality, representatives of Amphipoda dominated with a single species Grammarus roeseli, which was quite representative in numbers. In this locality tolerant spices are dominant with about $82 \%$

In the second locality in the middle flow of the river in Malisheva town, the river bed is cemented and represents a highly modified environment for the water organisms. However, in this locality a highly rich bental fauna used to be present. In this part of the river the order Diptera dominated with highly abundant Simulium sp., followed by Ephemeroptera comprised with three species, among which Baetis muticus dominated, while the number of other species was smaller. In the third locality the diversity of taxonomic groups increased and again order Diptera comprised $83 \%$ of macroinvertebrate sample, represented only by Simulium sp. with 1153 individuals. In this locality semi-tolerant species have dominated by about 97\%. With regards to values of Biotic index- BI, they variate from 5.58 in L1, 5.80 in L2 and 5.89 in L3.The Shannon- Wiener Diversity Index $(\mathrm{H})$, is very low in L1, only 0.06 , in L2 increases to 1.11 , to decrease again in L3 to 0.88 .

\section{Discussions}

The values of Hilsenhoff biotic index (BI) and the values of the Shannon- Wiener Diversity Index H, suggest a deterioration of waters of MirushaRiver with organic pollution. According to the Biotic Index, the water in the first locality in Banja e Malisheva is of a fair quality, while regarding the two other localities belonging to the middle and downstream of the river, the quality of water is even worse. The diversity index in the first locality is very low and indicates a poor fauna. This can be justified by the fact that in this locality the river is joined by the thermal water source, which highly increases the temperature of water, reaching the values of $19.5-24^{\circ} \mathrm{C}$, which is not favorable forthe most sensitive benthic organisms, and particularly can affect the trophic structures of ecosystem.

The situation improves in L2 and L3, expressed as the registered number of families (11-15) which is connected to the stability of the environment (Wynes and Wissing, 1981). During this research, a 
decreasing number of macroinvertebrate families along the downstream of the river Mirusha is registered, which suggest the presence of environmental pressure.

The evidenced change of the macro invertebrate's structure does not only suggest the presence of pollution, but also the change of the water flow types. The change of type, position and structure of the river bed corresponds with the changes in the structure of macro invertebrates, therefore, the third locality is characterized by the presence of Ephemeroptera, Diptera, Trichoptera, etc, and other groups which are typical for the middle and downstreams. This state of the Mirusha river is quite similar to the middle and downstreams of other rivers in Kosovo (Gashi, 2006, Zhushi - Etemi 2005, Grapci 2002), as a result of anthropogenic pollution from discharges of untrated waste waters as well as from agriculture, industry and other activities.

\section{Conclusions}

Based on the findings of this research, we consider that the benthic macroinvertebrate community of the Mirusha river is poor and reflects the level of pollution of the river. The findings also suggest the endangerement of the benthic fauna of the Mirusha river, which is a continuous threat from the anthropogenic factor. In the future, measures need to be taken in favor of protection of this river with special values not only to the area of Mirusha, but also to the entire territory of Kosovo, by applying different methods of monitoring aming to prevent various forms of anthropogenic pollution.

\section{References}

[1] De Pauw, N., Ghetti, P. F., Manzini, P. and Spaggiari, P., (1992). 'Biological assessment methods for running water'. In: River Water Quality - Assessment and Control, Newman, P., Piavaux, A. and Sweeting, R. (Eds), EUR 14606 EN-FR, 1992-III. Commission of the European Communities: Brussels, Belgium, pp. 217-248.

[2] Rosenberg, D. M. and Resh V. H., (1982). 'The use of artificial substrates in the study of freshwater benthic macroinvertebrates'. In: Artificial Substrates, Cairns, J. (Ed.) Ann Arbor Science: Ann Arbor, MI, USA, pp. $175-235$.

[3] Metcalfe-Smith, J. L., (1994). 'Biological water quality assessment of rivers: use of macroinvertebrate communities'. In: The Rivers Handbook, Vol. 2. Calow, P. and Petts, G. E. (Eds). Blackwell Scientific Publications: Oxford, UK, pp. 144-170.

[4] Hering, D., Moog, O., Sandin, L. and Verdonschot, P., (2004). 'Overview and application of the AQEM assessment system'.Hydrobiologia, 516, 1-20.

[5] Cairns, J., Jr., and J.R. Pratt. 1993. A history of biological monitoring using benthic macroinvertebrates. Pages 11-27 in D.M. Rosenberg and V.H. Resh, eds. Freshwater Biomonitoring and Benthic Macroinvertebrates. Chapman and Hall, New York, NY. 488 pp.

[6] WFD (2000). Water Framework Directive - Directive of EuropianParlament end of the Council 2000/60/EC Establishing a Framework for Community Action in the Field of Water Policy.

[7] Tachet, H., P. Richoux, M. Bournaud\& P. Usseglio Polatera, 2000. Invertébrésd'eaudouce. Systématique, biologie, écologie.CNRS Editions, $588 \mathrm{pp}$.

[8] Hilsenhoff, W. L., (1988).'Rapid field assessment of organic pollution with a family-level biotic index'.J. North Am. Benthol. Soc., 7, 65-68.

[9] Gashi, A. (2006). Analiza biocenologjike dhe ekologjike e makrozobentosit dh nektonit në lumin Llap.

[10] ZhushiEtemi F.(2005): Biological evaluation of River Sitnica based on macroinvertebrate composition, PhD thesis,University of Prishtina"HasanPrishtina"

[11] Grapci - Kotorri L. (2002). Hulumtim i makrorofaunës së bentosit në rrjedhen e lumit Drini i Bardhë dhe roli i saj në distrubuimin e llojeve të peshqve Salmo trutta fario L. dhe Barbus barbusL. Punimi i magjistraturës, Prishtinë.

[12] MMPH. (2012). Monumenti i Natyrës me rëndësi të veçantë “Ujëvarat e Mirushës”.Prishtinë: MMPH.

[13] Richard W. Merritt and Kenneth W. Cummins, 1996: An Introduction to the Aquatic Insects of North America Kendall/Hunt Publishing Company, 1996 - Nature - 862 pages. 